\title{
Evaluation of the energy production efficiency of CHP systems during the summer and winter season operation on the cogeneration unit
}

\author{
Miroslav Rimár ${ }^{1}$, Milan Abraham ${ }^{1, *}$, Marcel Fedak ${ }^{1}$, Jakub Váhovský ${ }^{1}$, and Andrii \\ Kulikov $^{1}$ \\ ${ }^{1}$ Technical university of Kosice, Faculty of Manufacturing Technologies with a seat in Prešov, \\ Bayerova 1, 08001 Prešov, Slovak Republic
}

\begin{abstract}
The main idea of using combined heat and energy production is to reduce usage of primary fuels and with that connected reducing of pollutions due to the integration of renewable energy sources and with regard to the natural environment. Presented contribution is dedicated on issue on the operation of a cogeneration unit integrated in central heating system. The purpose of currently contribution is to analyse and compare effectivity of cogeneration unit in each summer and winter season.
\end{abstract}

\section{Introduction}

Term combined heat and power supply nowadays is becoming and important issue for power generation management. Integration of cogeneration systems and renewable energy for heat generation on the basis of act no. 309/2009 [1] is becoming an important part of the energy generation. This integration into the national heat and power generate network may be either as separate sources or as a part of central systems for the power and thermal energy generation. Presented contribution is oriented to describe installed cogeneration unit driven by natural gas functioning on diesel principle which produces heat and electric energy. The main objective is in describing and comparing effectivity in individual summer and winter seasons. In addition, the conventional cogeneration system has been set optimally according to economic and energy requirements with respect to environmental criteria and controlled automatically through microcontrollers. The main idea on installing cogeneration is to reduce cost of energy and reducing pollution due to the integration of renewable energy sources such as biogas etc. Several existing installed systems demonstrated that there is many useless heat in summer seasons and that is reason for building accumulation or water storage tanks to save heat and use it for example in peaks when people need the hot water. When implementing energy sources, it is necessary to

\footnotetext{
* Corresponding author: milan.abraham@tuke.sk
} 
consider with implementation directive of the European parliament and of the Council of EU 2012/27/EU on energy efficiency $[1,2]$.

\section{Term cogeneration}

Heat supply nowadays requires part of primary energetic source and easiest way is to burn right fuel and by transfer send to heat customer. Effectivity of this transformation is high effective $(80-100 \%)$ but it loses exergy of fuel (ability to do mechanical work with the released heat). Energetically much more superior way to obtain heat is by using cogeneration, which represents combined production of electrical energy and heat. The main part of cogeneration unit is modified engine which are powering usually asynchronous generator. Engine modification consists of replacement of classic carburettor by mixing device for air and natural gas. Thermal energy from cooling engine and heat from exhausted gases for heating is collected by a system of heat exchangers. Thermal energy from engine is being transferred by water at temperature $70 / 90{ }^{\circ} \mathrm{C}$. Engine with generator are connected in one unit using the elastic silent block attached to the frame as shown at Figure 1. $[1,2]$.
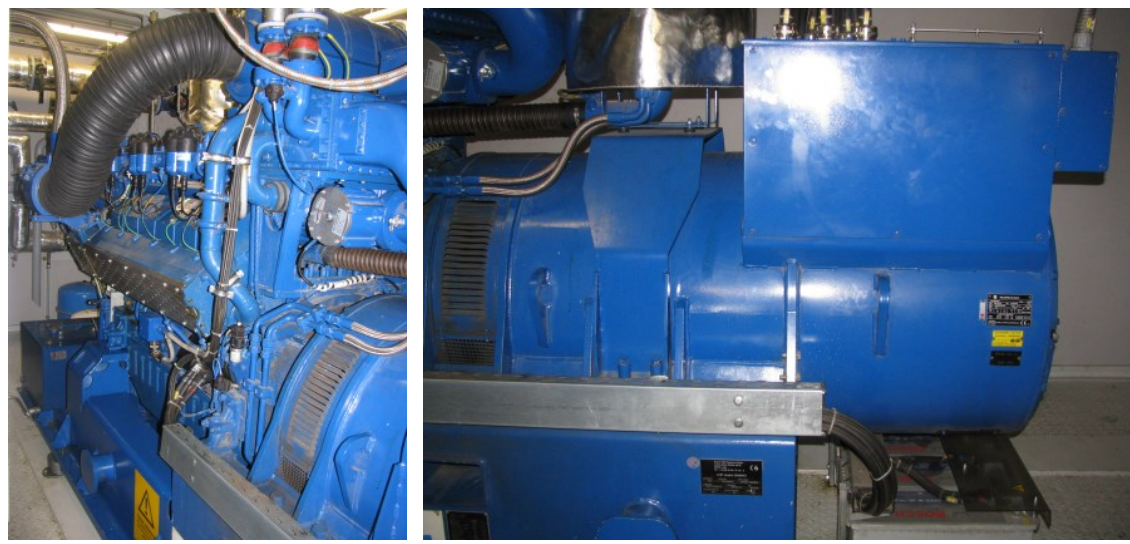

Fig. 1. Cogeneration unit engine with generator.

The production of heat and its delivery as final product is a sector whose operation is important not only from the point of view of industrial generation processes, but also from a social point of view. Presented cogeneration unit heats and prepares hot water for about 1600 apartments, elementary school and shopping centers. Cogeneration unit itself consists of gas combustion engine MWM/TCG 2016 V12C with generator which provides $600 \mathrm{~kW}$ of electrical rated power and $652 \mathrm{~kW}$ of thermal nominal power.

\section{The efficiency of the cogeneration unit}

The electrical efficiency of this cogeneration unit is about $39 \%$. To the quantity of consumed fuel, we add calorific value which is around $10.761 \mathrm{kWh} . \mathrm{m}^{-3}$ and we will get theoretical energy included in that amount of fuel [8]. By summing each electric energy and thermal energy and dividing it by theoretical energy included in fuel we get $\%$ effectivity of cogeneration unit. Average fuel consumption in year 2017 is around $81500 \mathrm{~m}^{3}$ of gas. Monthly fuel consumption is shown in Figure 2. Graphics values shows that cogeneration unit in summer season is very ineffective and in winter season effectivity is around $82-$ $87 \%$ which is still a little. Low values can cause overexposure system. From the point of 
view of the generation of thermal energy for the final customer the advantage of the central heat supply compared to other forms are relatively low prices for heat, in connection with the increase of the usage of cogeneration $[7,8]$.

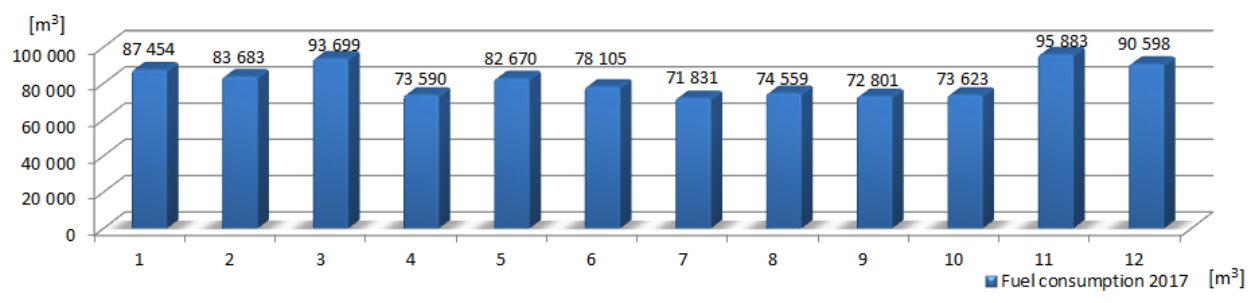

Fig. 2. Fuel consumption of cogeneration unit in 2017.

Monitored value of produced electric energy and heat is shown in Figure 3 separately. Total average effectivity of monitored cogeneration unit is around $87 \%$. The priority on the production of cogeneration unit is in thermal energy as shown in the figures. Overall power of cogeneration unit was not recorded, the only recorded values are shown at figures.

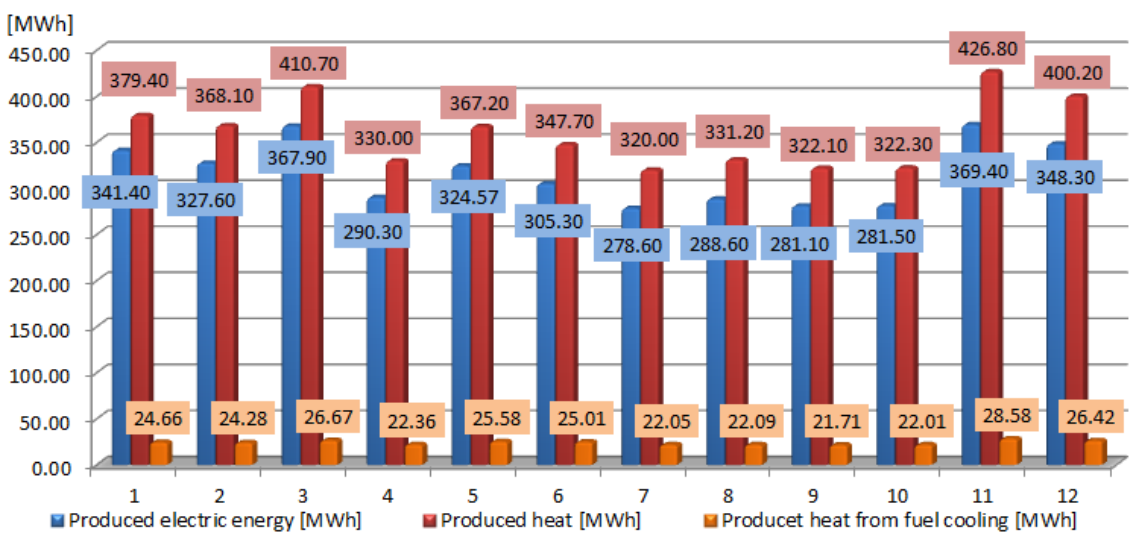

Fig. 3. Comparison of produced electric energy and heat in 2017 [MWh].

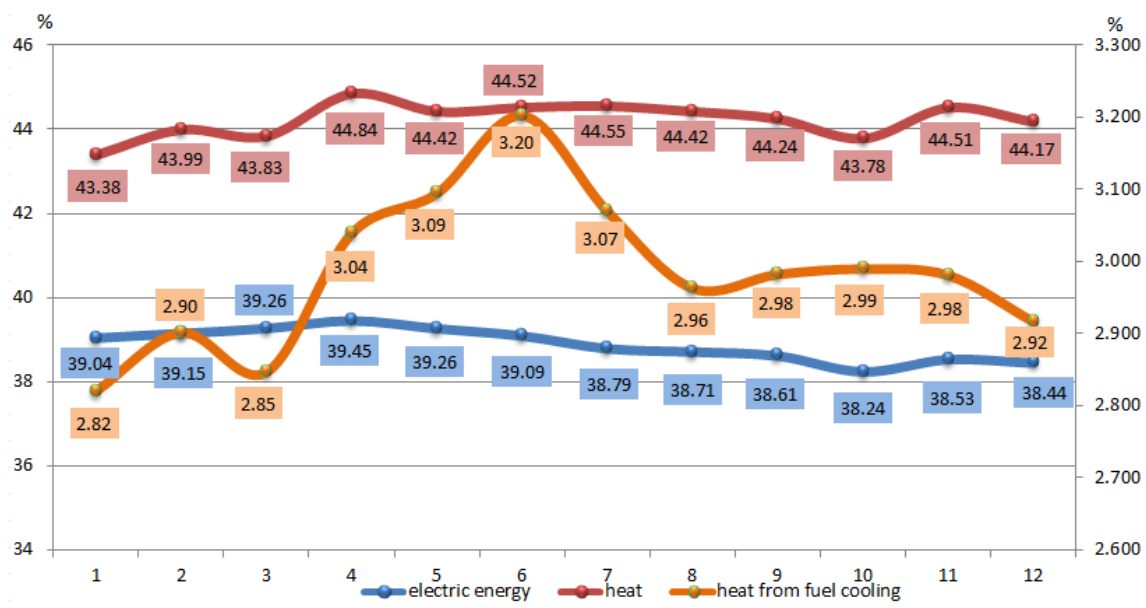

Fig. 4. Effectivity of each energy production separately [\%]. 
The theoretical and measured values lead to knowledge which you can read above that allows understanding the cogeneration unit effectivity and compares the effectivity in summer and winter seasons. Figure 4 describe effectivity of each produced energy in percentage. Measured values shows that there are not big differences in produced electric energy. The largest differences in produced energy are in heat from cooling fuel as shown in Figure 4 [4].

\section{Conclusions}

Since natural gas is the dominant fuel for the production of heat, greater emphasis need to be placed on combined energy production methods and directly connected to cogeneration. As shown, there is a direct correlation between the generated electrical energy and the heat in combined heat and energy production. Figures confirm problems with non-economical usage of cogeneration unit and shows that whole system is ineffective in summer season, in winter season efficiency of cogeneration unit is around $87 \%$. Compared to conventional thermal energy and electric energy production cogeneration is effective but there are still many others systems that could be more effectively. Heat from fuel cooling has higher value in summer seasons compared to heat from engine, due to operating hours and performance value of running cogeneration unit.

This work was supported by the Slovak Research and Development Agency under the contract No. APVV-16-0192

\section{References}

1. Act No. 309/2009 Coll. on promotion of renewable energy sources and high efficiency combined generation, and on amendments and supplements of certain Acts in the version of latter provisions

2. Directive 2004/8/EC of the European Parliament and of the Council of 11 February 2004 on the promotion of cogeneration based on a useful heat demand in the internal energy market and amending Directive 92/42/EEC

3. E. Dvorský, P. Hejtmánková, BEN - Technická literatúra (2005)

4. J. Krbek, L. Ochrana, B. Polesný, Heat supply and cogeneration (1999)

5. M. Rimár, P. Skok, Thermodynamics (2013)

6. M. Struž, Utilization of CHP in Slovakia and its further outlook (2014)

7. M. Rimár, M. Fedak, Combustion processes (2014)

8. Hodnoty vážených priemerov kvalitatívnych parametrov zemného plynu, ktorý na území Slovenskej republiky distribuuje spoločnost' SPP - distribúcia, a. s. Bratislava

http://www.spp.sk/sk/velki-zakaznici/zemny-plyn/o-zemnom-plyne/emisie/ 